\title{
Factors Influencing Household Perceptions of Drought in Laikipia West Sub County, Kenya
}

\author{
Amon Karanja, Kennedy Ondimu, Charles Recha \\ Department of Geography, Egerton University, Njoro, Nakuru, Kenya \\ Email: amon.karanja@egerton.ac.ke, kondimu@egerton.ac.ke, Charles.recha@egerton.ac.ke
}

How to cite this paper: Karanja, A., Ondimu, K. and Recha, C. (2017) Factors Influencing Household Perceptions of Drought in Laikipia West Sub County, Kenya. Open Access Library Journal, 4: e3764.

https://doi.org/10.4236/oalib.1103764

Received: June 25, 2017

Accepted: December 3, 2017

Published: December 6, 2017

Copyright ( 2017 by authors and Open Access Library Inc.

This work is licensed under the Creative Commons Attribution International License (CC BY 4.0). http://creativecommons.org/licenses/by/4.0/

\section{Open Access}

\begin{abstract}
The need for perception studies to drought is informed by the fact that different people perceive drought differently and derive local adaptation measures based on their individual perception. The objective of the study was to establish the household perceptions to drought and the factors that influence formation of such perceptions in Laikipia West sub-County, Kenya. The study adopted a household survey research design. The study utilized household surveys $(\mathrm{N}=180)$. Logistic regression was used to identify the factors influencing drought perception in Laikipia West sub-County. The study found that $52.8 \%$ of the households felt that the 2009 drought was moderate and $47.2 \%$ the drought was severe. Drought perception was significantly related to age, source of income, and type of land ownership and the length of engagement in farming. The study recommends that formulation of the future policies on drought adaptation strategies in Laikipia West sub-County should take into consideration the household drought perception for effective implementation.
\end{abstract}

\section{Subject Areas}

Natural Geography

\section{Keywords}

Perception, Adaptation Measures, Drought, Household Survey

\section{Introduction}

Drought adaptations depend on how drought is perceived at household level. The way local communities perceive drought influences their adaptation measures and coping strategies. Different people perceive drought differently and derive local adaptation measures based on their individual level perception. Research shows that any attempts to elicit adaptive behavior patterns should come 
after understanding how climate variability is perceived by stakeholders and what shape their perceptions [1] [2]. Lack of attention to adaptation may be due to a lack of understanding or poor perceptions of climate variability risks relative to other risks among a large part of the population [3]. [4] characterized the understanding of climate variability and change in the context of multiple livelihood risks. Research findings underline the importance of tackling both climatic and non-climatic conditions in enhancing adaptation.

According to [5] residents of Nairobi, Kenya do not perceive climate change as being a significant problem when compared to other socio-economic problems such as corruption, unemployment, crime, garbage and poverty. Understanding individuals' perceptions of, or concern about, extreme weather events is very important for designing and implementing climate adaptation policies. Individual judgments of climate change-related risks can determine the perceived legitimacy as well as compliance with adaptation policies [6]. Climate variability is a complex problem for individuals' [7] which implies that understanding the cognitive dimension and perceptions is very important for climate variability adaptation. The absence of perceived importance to the public and lack of public awareness or demand to take action are the main hurdles to implementation of adaptation projects [8].

Individual perceptions of natural hazards are important factors influencing decision-making mitigating these risks [9] [10]. For example, high flood-risk perceptions of individuals are related to a high demand for flood insurance [11]. Similarly, perceptions of extreme weather risks at the organizational level can be expected to be an important factor influencing the resources that an organization is willing to devote to drought adaptation. According to [12] individuals who have experienced an intense, life threatening event have a significantly higher level of concern than those without such an experience. This suggests limited intervention possibilities for communication of adaptation, as well as for raising support for adaptation measures. Framing adaptation measures in relation to personal circumstances and emotions during extreme events could help raise concern about extreme weather events, as well as societal support for adaptation measures.

According to [13] the term climate change was very familiar with the participants in Tharaka, Kenya as they had heard it from the radio and agricultural officers. There was unanimous agreement that there was climate change in Thara$\mathrm{ka}$ and this was attributed to cutting of trees which had a cooling effect on the environment. According to [14] majority of the farmers in Kyuso, Kitui County, Kenya were well aware that climate was changing and it was the cause of the recurrent droughts that were ravaging the district. Majority of the farmers noted that there was an increase in temperature, extended periods of temperature, a decrease in precipitation, changes in the timing of rains and an increase in the frequency of droughts.

According to [15] farmers' perceptions to drought effects on livestock prices 
vary widely. Although about $33 \%$ of the commercial and $20 \%$ of the communal farmers report that drought has no effect on livestock prices, most farmers think that livestock prices fall from $10 \%$ to $50 \%$ during drought. On the average, commercial farmers report that cattle prices decrease about 15\% during drought conditions, and communal farmers report an average decrease of $27 \%$. Due to the lower market prices of livestock, many commercial farmers do not sell animals in drought conditions unless they can receive the normal price for their animals. It is against that background that the study analyzed the social economic characteristics of the households that influence perception to drought in Laikipia West sub-County, Kenya.

\section{Study Area and Research Methodology}

The study area is Laikipia West sub-County in Laikipia County, Kenya. Laikipia means treeless plain in Maasai language [16]. Laikipia West sub-County is located to the north west of Mount Kenya. The sub-County lies between Latitude $0^{\circ} 15^{\prime}$ and $0^{\circ} 43^{\prime}$ North and between longitudes $36^{\circ} 30^{\prime}$ and $36^{\circ} 5^{\prime}$ East and an area of $3188.8 \mathrm{Km}^{2}$ as shown in Figure 1 . The altitude of the sub-County varies between $1000 \mathrm{~m}$ above sea level and $2600 \mathrm{~m}$ [17]. Laikipia West sub-County has four administrative wards namely; Rumuruti, Muhotetu, Sipili and Olmoran [18].

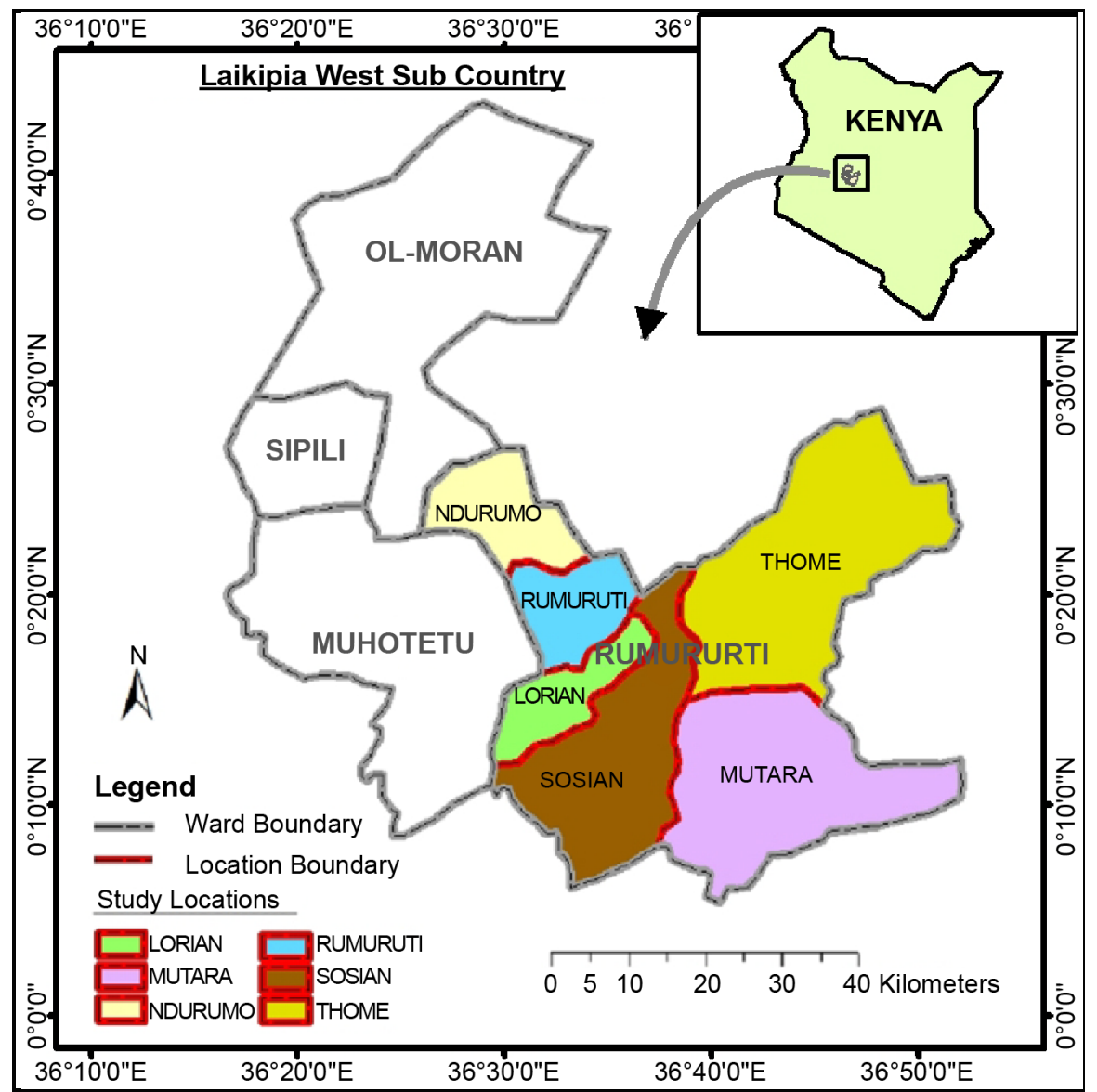

Figure 1. A map of Laikipia West sub-County showing the sampled sites. Source: [22]. 


\subsection{Climate and Agro-Ecological Zones}

The study area is located in the rain shadow of Mount Kenya making the area dry. The sub-County has humid, semi humid and semi-arid agro-ecological zones. These are UH 2-3 (Humid zones), LH 2-5 (Semi-humid zones); UM 6 and LM 6 (Semi-arid zones) [19]. Laikipia West sub-County is classified as 50\% - 85\% Arid and Semi Arid Land with annual rainfall varying between 500 and $800 \mathrm{~mm}$ [20]. Daily temperatures vary with altitude and season; mean temperatures range within $22^{\circ} \mathrm{C}-26^{\circ} \mathrm{C}$ and minimum and maximum temperature are $6^{\circ} \mathrm{C}-14^{\circ} \mathrm{C}$ and $35^{\circ} \mathrm{C}$ respectively. Due to the sub-County leeward position North West of Mount Kenya, it is comparatively dry despite its location on the Equator. The spatial distribution and the temporal viability of rainfall are strongly influenced by Mount Kenya and Aberdare ranges. Rainfall follows the seasonal movements of the Inter Tropical Convergence Zone (ITCZ) resulting in two rainfall seasons [21].

\subsection{Sampling Procedure and Sample Size}

The study used Slovin's formula [23] to determine the number of household respondents. Slovin's formula allows a researcher to sample the population with a desired degree of accuracy. Slovin's formula is written as

$$
n=N /\left(1+N e^{2}\right)
$$

where:

$$
\begin{aligned}
& n \text {-Sample size, } \\
& N \text {-Total population, } \\
& e \text {-Error of tolerance }=0.05 .
\end{aligned}
$$

Laikipia West sub-County had 39,966 households translating to 196 calculated households. Multistage cluster sampling technique was used to select respondents and study site. Administrative wards were clustered based on their different economic activities. There are four wards in Laikipia West sub-County (Figure 1). The wards are: mixed livelihood zones which comprise of Muhotetu and Sipili and sub-humid agro-pastoralism livelihood zone comprising of $\mathrm{Ru}$ muruti and Olmoran. In stage one; purposive sampling was used to select the study ward. The selected ward was Rumuruti whose choice was based on variation in livelihood options. The selection of Rumuruti ward a sub-humid agro-pastoralism was informed by the fact that, drought impacts on household livelihood and adaptations strategies are determined by economic activities of the households. Stage two involved proportionate random sampling to select household respondents from all the six locations in Rumuruti ward as shown in Table 1 using the following formula.

$$
n=p / \mu \times 300
$$

where;

$n$ is the sample population of the location.

$P$ is the population of the household in the location. 
Table 1. Households sample population in Rumuruti Ward.

\begin{tabular}{ccc}
\hline Location & Total Population & Sample Population \\
\hline Rumuruti & 16,094 & 67 \\
Thome & 6612 & 28 \\
Ndurumo & 6030 & 25 \\
Mutara & 6226 & 26 \\
Sosian & 6422 & 27 \\
Lorian & 5536 & 23 \\
Total & 46,920 & 196 \\
\hline
\end{tabular}

$\mu$ is the total households in the ward.

Rumuruti Ward has six locations namely: Rumuruti, Lorian, Ndurumo, Mutara, Thome and Sosian. The Ward has eleven sub-locations namely: Rumuruti Township, Mutamaiyo, Lorian, Ndurumo, Kagaa, Mutara, Kiamariga, Thome, Mathira, Sosian and MaunduMiiri.

\subsection{Data Collection}

Cross-sectional household survey was used to collect household data on the household perceptions to drought disasters. Household surveys are carried out to gather statistical information about the attributes and actions of a population by administering standardized questions to some of its members [24]. Household data was collected from proportionately random selected household in all the Locations in the selected Ward through structured questionnaires. The information sought from household include: social economic characteristics of the households and their perceptions to drought disasters. Out of 196 questionnaires administered, 195 were filled and returned, however 15 questionnaires were incomplete and therefore not considered during data analysis. One hundred and eighty questionnaires were considered during data analysis representing $92 \%$ response rate, which is considered satisfactory to make conclusions for the study. According to [25] a 50\% response rate is adequate, $60 \%$ good and above $70 \%$ response rate very good.

\section{Results and Discussions}

\subsection{Perception of Drought Events in Laikipia West Sub-County}

Assessment of drought perception is important because different people perceive drought differently and derive local adaptation measures based on their individual perception. Factor influencing drought perceptions were analyzed in order to explain why households living within the same neighborhood perceive drought differently.

The measureable indicators of perception in the study were operationalized as severe and moderate. The assumption made in the conceptualization of drought risk in the mentioned categories was that the perceived impact of drought to an 
individual household could have been determined by their past impacts. This is what [26] refer to as risk perception; the local people's own interpretation of the likelihood of being exposed to the content of risk. Assessment of local people's perceptions and attitudes informs us much more about the relevance of the adaptation strategies they are likely to adopt. Household perceptions of drought were categorized into two classes namely: severe and moderate. The results presented in Table 2 shows that out of 180 respondents $52.8 \%$ of the households felt that the 2009 drought was moderate and $47.2 \%$ drought was severe. The difference in their perception could be as results of the difference in socioeconomic characteristics of the households such as; age, gender, education, source of income, experience, agriculture training among others. The variation of respondents' responses on the drought characteristics shows that drought impacts differently among households in the same neighborhood.

The households that are more vulnerable and less resilient are likely to be more impacted as opposed to the households that are less vulnerable and could be more resilient. The variations of drought characteristics could also lead to adoption of different drought adaptation strategies among different household living in the same region experience common physical characteristics. Perception of drought informs households decision on short term and long term adaptation strategies that need to be put in place in Laikipia West sub-County.

\subsection{Factors Influencing Households Perception to Drought}

In order to determine the factors that influence household perception to drought the independent and dependent variables were regressed using logistic regression model and the results presented in Table 3 . The dependent variable was the question on how households described the 2009 drought as either severe or moderate. The result in Table 3 shows that gender of the household head was not significant to perception of drought in Laikipia West sub-County. This could be because pastoralism as a source of livelihoods involves members of either gender and suffer the impacts equally. It is expected that men are more likely to perceived drought more severely than women; this could be because of the mobility nature of men and this was not the case in Laikipia. In Laikipia gender is not factor affecting households' perception to drought.

The results show that the perception to drought among respondents who are $51-60$ years better perceive drought than the lower age categories $(\mathrm{p}=0.0004)$ compared to those below 30 years. These could be because of experience with

Table 2. Drought characteristics in Laikipia West sub-County $(\mathrm{N}=180)$.

\begin{tabular}{ccc}
\hline & Frequency & Percent \\
\hline Severe & 85 & 47.2 \\
Moderate & 95 & 52.8 \\
Total & 180 & 100.0 \\
\hline
\end{tabular}

Source: Field data (2016). 
Table 3. Odd ratios for logistic regression model on the factors influencing households perception to drought.

\begin{tabular}{|c|c|c|c|}
\hline Parameters & Coefficient Estimates & Wald & Odd ratio estimate \\
\hline \multicolumn{4}{|l|}{ Gender } \\
\hline Male (r) & & & 1.00 \\
\hline Female & -0.00127 & 0.9975 & 0.999 \\
\hline \multicolumn{4}{|l|}{ Age } \\
\hline$<30(\mathrm{r})$ & & & 1.00 \\
\hline $31-40$ & -0.2443 & 0.6204 & 0.783 \\
\hline $41-50$ & -0.7350 & 0.2310 & 0.480 \\
\hline $51-60$ & -0.6184 & $0.0004^{*}$ & 0.539 \\
\hline 61 and above & -0.3007 & 0.7228 & 0.740 \\
\hline Education & & & 1.00 \\
\hline \multicolumn{4}{|l|}{ Informal education $(r)$} \\
\hline Primary education & 0.0841 & 0.8653 & 1.088 \\
\hline Secondary education & 0.2095 & 0.7348 & 1.233 \\
\hline Tertiary education & -1.3791 & 0.1045 & 0.252 \\
\hline \multicolumn{4}{|l|}{$\begin{array}{l}\text { Length of engagement in } \\
\text { farming }\end{array}$} \\
\hline$<5(\mathrm{r})$ & & & 1.00 \\
\hline $6-10$ & 0.0784 & 0.9345 & 1.082 \\
\hline $11-15$ & 1.2508 & 0.1896 & 3.493 \\
\hline $16-20$ & 1.6412 & 0.1271 & 5.162 \\
\hline $21-25$ & 1.7086 & $0.0203^{*}$ & 5.521 \\
\hline $26-30$ & 1.3424 & 0.1714 & 3.828 \\
\hline \multicolumn{4}{|l|}{ Source of income } \\
\hline Government Employee (r) & & & 1.00 \\
\hline Business persons & -1.8852 & 0.0814 & 0.152 \\
\hline Maize farming & -1.5997 & 0.1382 & 0.202 \\
\hline Dairy farming & -0.7920 & 0.5158 & 0.453 \\
\hline Pastoralism & -2.1796 & $0.0473^{*}$ & 0.113 \\
\hline Wheat farming & 11.9681 & 0.9923 & 0.212 \\
\hline Size008_2 & -0.6723 & 0.1607 & 0.511 \\
\hline \multicolumn{4}{|l|}{ Size of land } \\
\hline$<2(\mathrm{r})$ & & & 1.00 \\
\hline $2-5$ & 2.0169 & 0.1189 & 7.515 \\
\hline $5-10$ & 0.3384 & 0.6477 & 1.403 \\
\hline \multicolumn{4}{|l|}{ Type of landownership } \\
\hline Owner (r) & & & 1.00 \\
\hline Leased land & 1.3224 & $0.0280^{*}$ & 3.753 \\
\hline Communal ownership & 0.8142 & 0.1231 & 2.257 \\
\hline \multicolumn{4}{|l|}{ Training } \\
\hline Yes (r) & & & 1.00 \\
\hline No & -0.8742 & 0.0928 & 0.417 \\
\hline \multicolumn{4}{|c|}{${ }^{*}$ Significant at $5 \%$ level of significance } \\
\hline \multicolumn{4}{|c|}{ Odds ratio $<1$ less likely to occur in the first group } \\
\hline \multicolumn{4}{|c|}{ Odds ratio $>1$ more likely to occur in the first group } \\
\hline \multicolumn{4}{|c|}{ Odds ratio of 1 indicates event under study is equally likely to occur in both groups } \\
\hline
\end{tabular}

Source: Field data (2016). 
drought events and respondents could compare the 2009 drought with other drought events in the past. They also fall within the productive age category. They are still engaged in livelihood activities. The insignificant results for the household above 60 years could be attributed to their overall population within the sample population in the study area

Contrary to the expectations results on education were not significantly related to drought perception. It was expected that educated households have learned the different drought magnitudes and could be able to categorize drought as either severe or moderate. It is also expected that household with primary education are likely to perceive drought than those with informal education. Households with secondary education are likely to perceive drought than households with informal education while those with tertiary education are less likely to perceive drought than those with informal education. However results show the education level is not significant to drought perception. Pastoralism being the major source of livelihoods in Laikipia West sub-County, effects of droughts does not discriminate and all the households' livelihoods are affected irrespective of their level of education.

The number of years a household has engaged in farming is positively related to their perception to drought. Length of stay in the study area was found to be significant to perception of the 2009 drought event $(p=0.0203)$. It is possible that experience of the environment (study site) has contributed to a better perception of the severity of drought. Lack of significant relationship to the 2009 drought perceptions for the household heads that have lived between 26 - 30 years in the study area can be attributed to their reduced interest in livelihood activities due to their advanced age. It should be noted that persons who have stayed in the study area for more than 26 years are in their $60 \mathrm{~s}$ and less involved in livelihood activities. This is perhaps due to their experience with weather events such as drought. According to an earlier study by [27] in North East Thailand farmers who have 30 years farming experience were less likely to believe that droughts were becoming more frequent; they believed that droughts frequency remain the same. On the other hand, farmers who have less than 30 years farming experience believed that drought will become more frequent in the near future. The results support the earlier argument by [28] on drought experience and perception of climatic change among great plains in the United State farmers, that if farmers do use the availability heuristic to form assessments of future drought, differences in the perception of drought frequency should arise from differences in the amount of individuals' experience.

According to the earlier study by [29] on perceptions of drought in the Ogallala Aquifer region in the United State, four coherent elements shape drought perception. Previous drought experiences shape an individual's memory and are an important influence on how someone defines drought. What one remembers as a drought depends on how an individual defines it; while on the other hand, what an individual defines as drought depends on the droughts one remembers. 
The way drought is defined and the way past droughts are remembered influence an individual's expectation of future droughts and one's behavior. In Laikipia West sub-County, the study on factors that influence drought perception was drawn in such way that the drought identifiable indicators were incorporated.

Pastoralism, as a source of income, was found to have significantly influenced the perception of the 2009 drought event $(p=0.0473)$. None of the other sources of income (Government employment, business, dairy farming, maize and farming), was found to have a significant relationship with perception of the 2009 drought. Although maize, wheat and dairy farming are more sensitive to drought than pastoralism, these may not be primary sources of income. To most households, pastoralism is the lead source of income. Thus, in the event of drought, most households are severely affected- this could be due to the sensitivity nature of pastoralism on drought event. Household employed by the government have a regular income which does not vary with the weather events compared to pastoralist who are worst hit due to decreased pasture.

The study further established that farming on leased land significantly influenced the perception of the 2009 drought event $(p=0.0280)$ than communal and privately owned land. This could be because the impact of drought in communal land ownership is a shared responsibility and not individual responsibility as in leased ownership. Similarly, households who own private land reserve the option not to engage in farming and therefore averting risks associated with land. It's significant to note that in Laikipia West Sub-County, most households with privately owned land are immigrants who own land and maize farmer and could opt not to cultivate crops when droughts are predicted to avoid losses unlike those on leased land that my still want to diversify the types of crops to recover money used to lease land.

Size of the land was not significant to drought perception in Laikipia West sub-County. It is expected that households with large portions of land are less likely to suffer the effects of drought compared to those with small portions of land. In a pastoralism dominated area large farmers allow greater grazing fields that small land sizes. With decreased pasture because of drought large portions of land are likely to have more pasture compared to small fields. The reason why land size is not significant to drought perceptions in Laikipia could be because of the presence of large tracks of land communally owned and also existence of absentee land owners. Training on agriculture was also not significant to household drought perceptions. It is expected that training broadens individual perceptions with the environment which is not the case in Laikipia West sub-County. This could be because of the mobile nature of the pastoralism as a source of income. The opportunities of interaction with extension officers and attending such trainings are minimal in pastoral realities.

\section{Conclusion and Recommendations}

Drought perception was significantly related to age, source of income, and type 
of land ownership and the length of engagement in farming. Perception to drought among different households leads to variations in response, preparedness and adaptation strategies applied by various households. The pastoralists are less likely to perceive drought than those employed by the government. This could be that people employed by the government could be more knowledgeable than pastoralist and can identify the different characteristics of drought. The study recommends that formulation of the future policies on drought preparedness in Laikipia West sub-County should take into consideration the household drought perception for effective implementation.

\section{Acknowledgements}

The authors of this article acknowledge the Egerton University, Division of Research and Extension for availing funds to support the publication of this article from the on-going research on drought effects on household livelihoods and adaptation strategies in Laikipia West sub-County, Kenya. The authors acknowledge the immense help received from the scholars whose articles are cited and included in references of this manuscript. The authors are also grateful to authors, editors and publishers of journals and books from where the literature of this article has been referred.

\section{Competing Interests}

Authors declared that no competing interests exist.

\section{References}

[1] Slegers, M.F.W. (2008) “If Only It Would Rain": Farmers' Perceptions of Rainfall and Drought in Semi-Arid Central Tanzania. Journal of Arid Environments, 72, 2106-2123. https://doi.org/10.1016/j.jaridenv.2008.06.011

[2] Weber, E.U. (2006) Experience-Based and Description-Based Perceptions of Long-Term Risk: Why Global Warming Does Not Scare Us (Yet). Climatic Change, 77, 103-120. https://doi.org/10.1016/j.jaridenv.2008.06.011

[3] Leiserowitz, A. (2005) American Risk Perceptions: Is Climate Change Dangerous? Risk Analysis, 25, 1433-1442. https://doi.org/10.1111/j.1540-6261.2005.00690.x

[4] Tscharkert, P. (2007) View from the Vulnerability: Understanding Climate and Other Stressors in the Sahel. Global Environmental Change, 17, 381-396. https://doi.org/10.1016/j.gloenvcha.2006.11.008

[5] Shisanya, C.A. and Khayesi, M. (2007) How Is Climate Change Perceived in Relation to Other Socio-Economic and Environmental Threat in Nairobi, Kenya. Climate Change, 85, 271-284. https://doi.org/10.1007/s10584-007-9321-9

[6] Peacock, W.G., Brody, S.D. and Highfield, W. (2005) Hurricane Risk Perceptions among Florida Single Family Homeowners. Landscape and Urban Planning, 73, 120-135. https://doi.org/10.1016/j.landurbplan.2004.11.004

[7] Swim, J., Clayton, S., Doherty, T., Gifford, G., Howard, G., Reser, J., Stern, P. and Weber, E. (2011) Psychology and Global Climate Change: Addressing a Multi-Faceted Phenomenon and Set of Challenges. Report of the American Psychological Association Task Force on the Interface between Psychology and Global Climate Change. American Psychological Association, Washington DC. 
[8] Archie, K.M., Dilling, L., Milford, J.B. and Pampel, F.C. (2012) Climate Change and Western Public Lands: A Survey of US federal Land Managers on the Status of Adaptation Efforts. Ecology and Society, 17, 20. https://doi.org/10.5751/ES-05187-170420

[9] Burn, D.H. (1999) Perceptions of Flood Risk: A Case Study of the Red River Flood of 1997. Water Resources Research, 35, 3451-3458. https://doi.org/10.5751/ES-05187-170420

[10] Flynn, J., Slovic, P., Mertz, C.K. and Carlisle, C. (1999) Public Support for Earthquake Risk Mitigation in Portland, Oregon. Risk Analysis, 19, 205-216. https://doi.org/10.1111/j.1539-6924.1999.tb00400.x

[11] Botzen, W. and van den Bergh, M. (2012) Monetary Valuation of Insurance against Flood Risk under Climate Change. International Economic Review, 53, 1005-1025. https://doi.org/10.1111/j.1468-2354.2012.00709.x

[12] Vasileiadou, A.E. and Botzen, W.J.W. (2014) Communicating Adaptation with Emotions: The Role of Intense Experiences in Raising Concern about Extreme Weather. Ecology and Society, 19, 36. https://doi.org/10.5751/ES-06474-190236

[13] Recha, C.W. (2013) Effects of Climate Variability on Water Resources and Livelihoods and State of Adaptive Capacity in Semi-Arid Tharaka District, Kenya. Unpublished PhD Thesis, Kenyatta University, Kenya.

[14] Ndambiri, H., Ritho, C., Mbogoh, S.G., Ng'ang'a, S., Muiruri, E.J., Nyangweso, P.M., Kipsat, J., Omboto, P., Ogada, J., Kefa, C., Kubowon, P. and Cherotwo, F. (2012) Analysis of Farmers' Perceptions of the Effects of Climate Change in Kenya: The Case of Kyuso District. Journal of Environment and Earth Science, 2, 74-83.

[15] Hudson, J.W. (2002) Responses to Climate Variability of the Livestock Sector in the North-West Province, South Africa. Unpublished Master Theses, Colorado State University, Fort Collins, Colorado.

[16] CDIDP (2013) First County Development Integrated Development Plan (2013-2017). Laikipia County.

[17] Thenya, T., Kiteme, B.P., Ouko, C.A., Kahiu, N., Njuguna, E.C., Karanja, F., Ojwang, D. and Wambugu, G. (2011) Assessment of Ecological Status and Socio-Economic Dynamic of Upper Ewaso Ng'iro Basin Wetlands. CETRAD.

[18] KNBS (2010) Kenya Population and Housing Census Volume 1(A). Ministry of Planning and Vision 2030. Government Printers, Nairobi.

[19] Jaetzold, R. and Schmidt, H. (1983) Farm Management Handbook of Kenya Vol. II. Ministry of Agriculture, Kenya in Collaboration with the German Agriculture Team (GAT) of German Agency for Technical Cooperation (GTZ).

[20] Jaetzold, R., Schmidt, H., Hornetz, B. and Shisanya, C. (2011) Farm Management Handbook of Kenya. Vol. II. Natural Conditions and Farm Management Information. 2nd Edition, Part B, Central Kenya Subpart B1b Northern Rift Valley Province, Ministry of Agriculture, Nairobi.

[21] Huho, J.M., Ngaira, J.K. and Ogindo, H.O. (2010) Drought Severity and Their Effects on Rural Livelihoods in Laikipia District, Kenya. Maseno University. Journal of Geography and Regional Planning, 3, 35-43.

[22] IEBC (Independent Electoral and Boundaries Commission) (2012) Electoral Boundaries in Kenya. Kenya Government.

[23] Galero, T.E. (2011) A Simplified Approach to Thesis and Dissertation Writing. Mandaluyong City. National Book Store, 43-44.

[24] Buckingham, A. and Saunders, P. (2004) The Survey Methods Work Book. Polity 
Press, Cambridge.

[25] Mugenda, O. and Mugenda, A. (2003) Research Methods. Revised Edition, Acts Press, Nairobi, Kenya.

[26] Pennings, J.M.E. and Smidts, A. (2000) Assessing the Construct Validity of Risk Attitude. Management Science, 46, 1337-1342. https://doi.org/10.1287/mnsc.46.10.1337.12275

[27] Abul, H., Amir, F. and Promkhambut, A. (2013) Farmers' Perception of Drought and Its Impact on Community in Rural North East Thailand.

[28] Diggs, D.M. (1991) Drought Experience and Perception of Climatic Change among Great Plains Farmers. Great Plains Research: A Journal of Natural and Social Sciences, 1, 113-132.

[29] Taylor, J.G., Steward, T.R. and Downton, M. (1988) Perceptions of Drought in the Ogallala Aquifer Region. Environment and Behaviour, 20, 150-175.

https://doi.org/10.1177/0013916588202002 